\title{
Determinants of the success of equity crowdfunding campaigns
}

\author{
Israel José dos Santos Felipe ${ }^{1}$ \\ (D) https://orcid.org/0000-0001-8608-0029 \\ Email: israelfelipe@ufop.edu.br \\ Bruno César Franca Ferreira ${ }^{1}$ \\ (D) https://orcid.org/0000-0002-0001-554X \\ Email: bruno.ferreira@aluno.ufop.edu.br
}

1 Universidade Federal de Ouro Preto, Instituto de Ciências Sociais Aplicadas, Departamento de Ciências Administrativas, Mariana, MG, Brazil

Received on 08.31.2019 - Desk acceptance on 09.27.2019 - $2^{\text {nd }}$ version approved on 01.08.2020 - Ahead of print on 05.11.2020

Associate Editor: Fernanda Finotti Cordeiro Perobelli

\begin{abstract}
Given that equity crowdfunding has grown significantly in Brazil and that this market has been frequently sought by startups as an alternative to scarce credit, this study investigated the elements that determine the success of their financing campaigns. The article fills the gap related to the absence of studies analyzing the probability and time of success of startup financing. In Brazil, the research on this is still in its infancy and there has been little discussion regarding what can determine the success of this type of financing. The findings presented here provide managerial contributions for different stakeholders, ranging from platform managers and entrepreneurs to the ordinary citizen, who ultimately acts as an inducer of change in society, without the need for financial intermediaries. The discussion around the elements that influence the success of startup financing has revealed that the characteristics of the venture profile have been able to determine the success of the financing. This information applied to the dynamic of resource allocation in this market can generate more financial efficiency for private agents as an investment performance parameter and, for public agents, as an input for monitoring. The logistic regression with marginal effects and a dummy for time fixed effects were used. The time of success analysis was carried out via survival models. The sample covers 99 startup financing campaigns from 2014 to 2017 . The study identified that the financial goal, the venture category, advisor participation, the campaign duration, and the type of equity offered to the investor positively affect both the probability and speed of success of the startup financing. Its contribution lies in the use of these findings to formulate strategies geared toward estimating success, which enable an appropriate allocation of financial resources.
\end{abstract}

Keywords: startup financing, fundraising, equity crowdfunding, fintechs, success.

Centro - Mariana - MG - Brazil 


\section{INTRODUCTION}

Micro and small businesses have faced certain difficulties in obtaining financing (Clarke, 2016), especially recently-created ones, which have no credit history or guarantees to offer as well as an insufficient cash fund to pay future debts (Berger, Espinosa-Vega, Frame, \& Miller, 2005). The vast majority of these companies do not have sufficient financial resources to develop their business in the short run and resort to external financing to develop their activities (Drover et al., 2017). However, as Cumming, Pandes, and Robinson (2013) report, external financing is not successful in all cases, given that recentlyformed and small-sized companies may not fulfill the minimum requirements set in the credit formalization.

In light of this, innovative companies, focused on the intensive use of technology and with accelerated growth potential, have managed to change the current scenario of credit constraints (Allison, Davis, Short, \& Webb, 2015). These companies are known as startups, which are able to obtain financing via angel investors, accelerators, incubators, or contributions from venture capital funds (Bapna, 2016). However, when the emergence of startups exceeds the capacity of accelerator and angel investor investments, one possible solution is the use of crowdfunding financing, as Mollick (2014) indicates.

Crowdfunding can be understood as the raising of small amounts from many financial backers, captured through the internet, without a traditional financial intermediary (Mollick, 2014). With respect to equity crowdfunding (henceforth called ECF), the focus of this paper, this is a crowdfunding modality that seeks investment from a group of people to finance startups, instead of an angel investor or other private-sector investment (De Buysere, Gajda, Kleverlaan, Marom, \& Klaes, 2012).

According to the Massolution ${ }^{\circledR}$ report (2015), the ECF market presented $182 \%$ growth in the period from 2014 to 2015 , accounting for US\$ 1 billion. This information reveals the economic and financial potential of this "new" startup financing and investment modality for people (Mollick, 2014). Despite this market clearly being on the rise in various countries (Felipe, Mendes-DaSilva, \& Gattaz, 2019), there has been little discussion about the elements that can lead to the success of ECF financing campaigns. Thus, the following question remains unanswered: which elements can promote success in an ECF financing campaign?

With the intention of contributing to the barely explored literature on the success of startup financing via ECF (Ahlers, Cumming, Günther, \& Schweizer, 2015), this study aims to identify which elements linked to the venture (startup) profile can lead to the success of ECF campaigns. The initial literature on this topic reports that it makes sense to believe that, by studying the elements capable of increasing or reducing the chances of success of ECF campaigns, relevant knowledge is generated for paying due attention to the economic, financial, and social potential of this collective financing modality (Drover et al., 2017).

With relation to what has been produced in Brazil on this topic, the number of studies on the crowdfunding market is still quite small and a large portion of these focus only on reward-based crowdfunding. For example, there is the work of Monteiro (2014), who verified the motivations for the participation of supporters of rewardbased crowdfunding and perceived that "helping others," "supporting a cause," "receiving rewards," and "forming part of a community" were the inducers of participation in this modality.

Amedomar (2015), in turn, investigated five technology-based companies (TBCs) that sought financing via reward-based crowdfunding. His research revealed that $\mathrm{TBCs}$ choose crowdfunding financing primarily due to the initial development stage they find themselves in. Moreover, the author suggests that the importance of the company and good divulgence of the venture can be useful elements for the success of the financing.

Araújo (2017) chose to examine which rewards strategies can enhance the success of ventures and understood that the strategies of exclusivity, pre-purchase, and co-creation of the venture may be fundamental for successfully obtaining financing. Felipe (2017) analyzed more than 4 thousand ventures that sought financing via reward-based crowdfunding and concluded that artistic projects that sought larger sums of money and that promised a greater number of rewards were less successful. Moreover, projects that obtained a greater number of contributions and ventures developed in regions with a higher concentration of income per capita were shown to be more successful.

These studies reinforce the perception that the focus of the academic investigations, at least on the Brazilian level, still lies in the reward-based crowdfunding market, perhaps because of the difficulty of obtaining data (Vulkan, Åstebro, \& Sierra, 2016), due to the competition itself 
between ECF platforms (Ahlers et al., 2015) or simply because of the lack of monitoring of the ventures after the financing campaigns are carried out (Block, Hornuf, \&
Moritz, 2018). There may, therefore, be an important gap in terms of studies for the ECF market, which is initially covered by this paper.

\section{ECF}

According to Ahlers et al. (2015) and Agrawal, Catalini, and Goldfarb (2016), ECF can be understood as a venture financing modality in which people invest funds in order to become partners. These authors indicate that the investors allocate financial resources in ventures (startups) and receive the capital invested in the form of pre-established (defined) equity or variable equity (outlined in accordance with the amount raised or the financial performance of the startup).

Mollick (2014) adds that, as it is a form of investment with operational risks and uncertainty attached, ECF needs specific regulations, as well as well-structured and transparent financial plans. In the case of Brazil, Instruction n. 588/2017 of the Comissão de Valores Mobiliários (the Brazilian capital market regulator) (CVM, 2017) was enacted in July of 2017, regulating the "public offering of securities in small-sized enterprises with exemption from registering an electronic platform for participative investment." This instruction presents in detail all the guidelines for companies that wish to seek financing via ECF, for investors in the businesses offered in this market, and for the platforms that host and manage the collective fundraising.

According to Vulkan et al. (2016), ECF is based on a shared investment agreement, where the advantage and differential is the possibility for small investors to have the opportunity to choose and participate in businesses that will be invested in with their funds (Cummings, Rawhouser, Vismara, \& Hamilton, 2019b). ECF financing operations primarily occur on online platforms (Vismara, 2016a). These platforms serve as a tool for the operationalization of the financial activities in the ECF market and can mitigate the cost of transactions (Vismara, 2019), since they reduce the information asymmetry during the sharing of information on the venture during the launch of the financing campaign (Belleflamme, Omrani, \& Peitz, 2015).

The financial relationships established in the ECF market can be interpreted as being bilateral (Haas, Blohm, \& Leimeister, 2014); that is, there is interaction between individuals who seek funding for their ventures (startups) and others who wish to invest their financial resources in a new investment opportunity ( $\mathrm{Da}$ Cruz, 2015; Vismara, 2019). Thus, it makes sense for there to be an economic relationship between demand (the need for credit) and supply (new investment opportunities) in this market.

Another relevant factor regarding the ECF market is the risk element (Walthoff-Borm, Schwienbacher, \& Vanacker, 2018). The operations carried out in this market present risk both for the investor, when they invest their capital in a venture that cannot deliver the financial result promised, and for the entrepreneur, given that they may choose a platform that is not aligned to the business offered and this implies the failure of their financing campaign (Walthoff-Borm et al., 2018).

The ECF platform acts as an intermediary agent, enabling entrepreneurs and investors to exchange information about prices and offers, in order to overcome information asymmetries and minimize financial transaction costs (Hornuf \& Schwienbacher, 2018). To attract these agents (entrepreneurs and investors), the platform chooses strategies (business viability, administration fee, etc.) and functionalities (portfolio for the entrepreneur/investor, website use, among others) to bring them together and make the financing campaigns more welcoming and available to the general public (Mahmood, Luffarelli, \& Mukesh, 2019; Piva \& RossiLamastra, 2018).

According to Hossain and Oparaocha (2017), ECF can be considered a viable investment alternative, since the assets available to be invested in by the public are not yet priced in the market, and there are no administration fees or costs of crowdfunding funds. The existence of syndicates and leader investors in this crowdfunding modality has increased the demand for the collective investment (Agrawal et al., 2016), with it being believed that syndicates are able to provide information and management of the investments made, as well as increasing the transparency of the business.

The reduction in uncertainty through the signals of venture quality and diffusion of financial information has increased the volume of investments made in ECF (Ahlers et al., 2015; Bapna, 2016). The literature on ECF 
indicates that the legalization of the activity and the creation of organizations that offer support to investors have contributed to the growth of businesses that use virtual platforms (Felipe, 2015), both for investments in ventures and for investments in individual projects (Ahlers et al., 2015). Thus, the demand for ECF as a financing/ investment modality has grown in recent years (Hornuf \& Schwienbacher, 2018).

\section{DETERMINANTS OF THE SUCCESS OF ECF CAMPAIGNS}

Kuppuswamy and Bayus (2017) argue that ECF investors are more prone to making financial contributions in the initial stages of a venture offer or in the final stages of the campaign, with these contributions being more significant in the initial stages of the ECF campaign launch.

Block et al. (2018) confirmed that the language used by the founder of the venture (in the online divulgence) and the updates regarding the development of the startup (campaign performance, new financing, business development, and cooperation projects) are important elements for motivating people to participate in the ECF. In turn, Lukkarinen, Teich, Wallenius, and Wallenius (2016) suggest that the success of ECF campaigns is related to the pre-chosen characteristics of the campaign (in this study we call this the venture profile) and the use of social media to divulge information on the financing campaign.

Signori and Vismara (2018) believe that the offer of voting shares in the ECF financing campaign should have an effect over the chance of success of the venture, as well as tax incentives. The purpose of the ECF project has a positive influence on the success of the financing, as indicated by Schwienbacher and Larralde (2010). According to these authors, the characteristic of whether the project profile presents the scope for profit or not can positively influence the decision to allocate investment in that market, and is thus a determining element of success.

Mollick (2014) argues that if the financing goal of the crowdfunding project is inconsistent with the real cost and scope of the business, the number of contributions made to that project tends to be relatively small. Vismara (2016b) corroborates that premise and argues that the value attributed as the goal of ECF projects should be a valuable resource for raising capital, since it can attract or repel investor participation. Ahlers et al. (2015) indicate that the goal of a project can be used as a factor for exploring the financial objective of an ECF venture; that is, there may be a significant relationship between the value attributed as the financing goal of a project and its chance of achieving success, as stated by hypothesis $1\left(\mathrm{H}_{1}\right)$.
$\mathrm{H}_{1}$ : the value defined as the financial objective (goal) of ECF ventures has a positive influence over the success of their financing campaigns.

In the literature on crowdfunding, there is a varied set of ventures undertaken in this business type, whose sizes and characteristics make them unique and mean the collective financing market is flexible and adaptable to different economies (Prpić \& Shukla, 2013). The participants in this market generally deposit financial resources in ventures that are capable of adding value to the economy and to society (Ahlers et al., 2015); that is, people's participation can be translated in the form of consumption of new products or services. This premise strengthens the idea that crowdfunding should take advantage of people's knowledge and preferences to improve products or services that were not previously available for immediate consumption (Belleflamme, Lambert, \& Schwienbacher, 2014) so that the category of the venture (whether it is a new product or service) should be able to influence its chance of success, as suggested by hypothesis $\mathrm{H}_{2}$.

$\mathrm{H}_{2}$ : the category the ECF venture forms part of has an influence over the chance of success of its financing campaign.

According to Dranove and Jin (2010), it is conceivable that the involvement of more experienced investors during the financing process can signal credibility of the venture. These authors argue that the participation of this type of investor has a positive effect over the chances of success of the financing campaign of a project in the ECF market. The presence of the advisor or of other reliable individuals (friends, relatives, or closely-related people with investment experience) can incentivize more financial contributions for businesses financed via ECF, given that these agents contribute to the evolution of the startup, providing experience in its business segment (Ahlers et al., 2015). Moreover, the involvement of such intermediaries in the venture can help to reduce relevant informational discrepancies for investment decision making in startups (Chesbrough, 2010).

Moritz, Block, and Lutz (2015) and Signori and Vismara (2018) argue that the participation of qualified 
(more experienced) investors during the financing phase can signal a superior venture quality and transparency to use necessary information for resource allocation decisions in the ECF market. Thus, $\mathrm{H}_{3}$ tests the premise regarding the effect of advisor participation over the success of ECF ventures.

$\mathrm{H}_{3}$ : the advisor's participation in ECF ventures has a positive influence over the success of their financing campaigns.

Colombo, Franzoni, and Rossi-Lamastra (2015) believe that some successful crowdfunding projects demonstrate greater fundraising capacity in the first days of the campaign and that, over time, their chances of success tend to decrease. Mollick (2014) agrees with this thinking, but highlights that reward-based crowdfunding projects that present a greater exposure period, that is, longer financing campaigns, signal doubt over their success and quality for their investors. Thus, it is important to verify the influence of the exposure period, called the duration here, of the venture over its financing campaign, as stated in hypothesis $\mathrm{H}_{4}$.

$\mathrm{H}_{4}$ : the duration of the ECF venture has a positive influence over the success of its financing campaign.

\section{METHODOLOGICAL ASPECTS}

\subsection{Database}

The dataset used in this research was provided by the first ECF platform in Brazil, Kria - Agente de Estruturação Ltda. (Figure 1), previously known as Broota. The data considered cover $99 \mathrm{ECF}$ venture campaigns in the period from 2014 to 2017. The campaign distribution over the periods analyzed was the following: 2014 (13 campaigns);
2015 (39 campaigns); 2016 (33 campaigns); and 2017 (14 campaigns). The financing goal of these campaigns totaled $\mathrm{R} \$ 15.5$ million and the final value raised by the campaigns of the successful ventures was more than $\mathrm{R} \$ 13$ million. The headquarters of the ventures analyzed in this research were in the cities of São Paulo, Rio de Janeiro, Belo Horizonte, Porto Alegre, Florianópolis, and Curitiba.
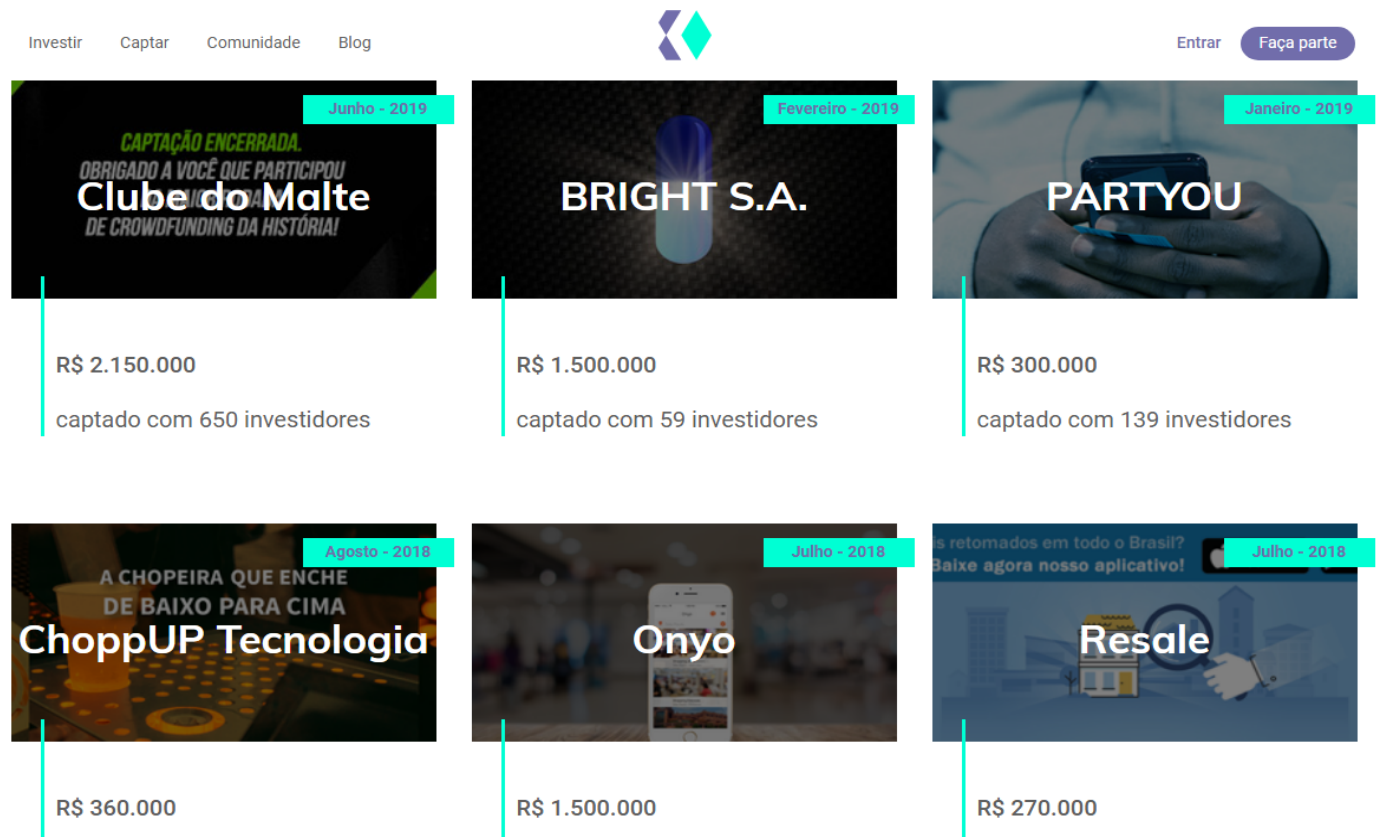

Figure 1 Equity crowdfunding (ECF) ventures hosted on the platform Kria - Agente de Estruturação Ltda. Source: Kria, 2019b. 
Kria is the biggest Brazilian platform for startup financing, operationalizing more than $\mathrm{R} \$ 31$ million in financing (Kria - Agente de Estruturação Ltda., 2019b). The platform has a portfolio of more than 2.7 thousand investors, 31 thousand connections, and more than 60 invested companies chosen based on selection criteria used by the platform itself.

The data provided for this study contemplate the general attributes linked to the profile of the ventures managed by the platform. These attributes refer to the financial goal of the ventures, the venture category, the presence of an advisor (qualified investor, that is, anyone who has had previous experience in the investments market) in the venture, the duration of the venture, the entrepreneur's gender (Greenberg \& Mollick, 2015; Marom, Robb, \& Sade, 2014), the stage of the venture (whether the business already exists and is actively billing or not), the type of participation offered to investors, and whether the fundraising round of the ventures presented a leader investor, that is, whether the venture offers were initially managed by investment syndicates.

According to the Kria platform (2019a), for every ECF project the participation of leader investors (led round) is obligatory. These leader investors may be either an angel investor or investment funds. The investors may feature as leaders of the investment round, acting as advisors to small investors in exchange for up to $20 \%$ of the profit made, as a kind of administration fee. Leader investors are suitable for creating syndicates that operate as a fund portfolio, in which small investors invest in a fund managed by the leaders instead of investing in individual financing campaigns (Kria, 2019a).

\subsection{Variables Employed}

The variables used in this study (tables 1 and 2) and their respective correlations (Table 3 ) were chosen by considering the current literature on the use of ECF as a financing alternative for different venture categories. This study considered two groups of variables (venture profile and controls) as determinants of the success of ventures financed via ECF.

The success of the ventures was treated as a dummy variable, in which the value 1 was attributed when the financing campaign of a particular project achieved at least two-thirds of the fundraising goal in confirmed investments; otherwise the value 0 was set. We used exactly the same strategy for classifying success of the campaigns (raising at least two-thirds of the financing goal) that the Kria platform adopted in the periods considered in this study.

With relation to the variables treated as venture profile, the following were used: the financial goal (logarithmized); the venture category (dummy $=1$ for product; 0 for service); the presence of an advisor in the campaign of the venture (dummy $=1$ for yes; 0 for no); and the duration of the campaign (number of days of fundraising). The variables used as a control were the entrepreneur's gender (dummy $=1$ if the entrepreneur's gender is male; 0 for female); the stage of the venture (dummy $=1$ if the stage of the ECF venture is active billing; 0 for prebilling); the type of equity (dummy = 1 if the venture is pre-established equity; 0 for variable equity); and the led financing round (dummy $=1$ if the venture had a leader investor's participation; 0 otherwise).

Table 1

Descriptive statistic

\begin{tabular}{|c|c|c|c|c|c|c|}
\hline & $\begin{array}{c}\text { Obs. } \\
(n)\end{array}$ & Mean & $\begin{array}{l}\text { Standard } \\
\text { deviation }\end{array}$ & Min. & Max. & Description of the variable \\
\hline Success & 99 & 0.46 & 0.50 & 0 & 1 & $\begin{array}{c}\text { Dummy }=1 \text { if the venture achieved success (fundraising greater } \\
\text { than two-thirds of the financial goal); } 0 \text { otherwise. }\end{array}$ \\
\hline Lgoal $^{\ddagger}$ & 99 & 5.34 & 0.78 & 3.91 & 7.29 & $L n$ of the financing goal of the ECF ventures. \\
\hline Category & 99 & 0.53 & 0.50 & 0 & 1 & Dummy $=1$ if the ECF venture offers a product; 0 for a service. \\
\hline Advisor ${ }^{\S}$ & 99 & 0.65 & 0.47 & 0 & 1 & $\begin{array}{c}\text { Dummy }=1 \text { if the ECF venture has an advisor's participation; } 0 \\
\text { otherwise. }\end{array}$ \\
\hline Duration & 99 & 88.23 & 51.72 & 4 & 197 & Duration in days of the ECF venture campaigns. \\
\hline GEnt & 99 & 0.73 & 0.44 & 0 & 1 & $\begin{array}{c}\text { Dummy }=1 \text { if the entrepreneur's (startup owner's) gender is } \\
\text { male; } 0 \text { for female. }\end{array}$ \\
\hline Stage & 99 & 0.55 & 0.49 & 0 & 1 & $\begin{array}{c}\text { Dummy }=1 \text { if the stage of the ECF venture is active billing; } 0 \\
\text { for pre-billing. }\end{array}$ \\
\hline Tequity & 99 & 0.47 & 0.50 & 0 & 1 & $\begin{array}{c}\text { Dummy }=1 \text { if the venture is pre-established equity; } 0 \text { for } \\
\text { variable equity. }\end{array}$ \\
\hline
\end{tabular}


Table 1

Cont.

\begin{tabular}{ccccccc}
\hline & $\begin{array}{c}\text { Obs. } \\
(\mathbf{n})\end{array}$ & Mean & $\begin{array}{c}\text { Standard } \\
\text { deviation }\end{array}$ & Min. & Max. & Description of the variable \\
\hline Rleader & 99 & 0.68 & 0.46 & 0 & 1 & $\begin{array}{c}\text { Dummy }=1 \text { if the ECF venture presented a led round (by an } \\
\text { angel investor, investment funds, or syndicate that invests in } \\
\text { startups); } 0 \text { otherwise. }\end{array}$ \\
\hline
\end{tabular}

* The mean in reais of the financing goal was $R \$ 218,776.16$.

$\S$ An investor that contributes to the evolution of the startup, providing their experience in the business segment.

Source: Elaborated by the authors.

Table 2

Descriptive statistic for separate groups (success vs. failure)

\begin{tabular}{lccccccccccccc}
\hline Success & $\begin{array}{c}\text { Obs. } \\
(\mathbf{n})\end{array}$ & Mean & $\begin{array}{c}\text { Standard } \\
\text { Deviation }\end{array}$ & Min. & Max. & Failure & $\begin{array}{c}\text { Obs. } \\
(\mathbf{n})\end{array}$ & Mean & $\begin{array}{c}\text { Standard } \\
\text { Deviation }\end{array}$ & Min. & Max. & $\boldsymbol{t}$ Test \\
\hline Lgoal $^{\ddagger}$ & 46 & 5.50 & 0.81 & 4.14 & 7.29 & Lgoal $^{\ddagger}$ & 53 & 5.19 & 0.73 & 3.91 & 6.65 & $-1.97^{* *}$ \\
\hline Category & 46 & 0.47 & 0.50 & 0 & 1 & Category & 53 & 0.58 & 0.49 & 0 & 1 & 1.05 \\
\hline Advisor & 46 & 0.80 & 0.40 & 0 & 1 & Advisor & 53 & 0.52 & 0.50 & 0 & 1 & $-3.03^{* * *}$ \\
\hline Duration & 46 & 95.82 & 47.43 & 25 & 197 & Duration & 53 & 81.64 & 54.76 & 4 & 171 & -1.38 \\
\hline GEnt & 46 & 0.76 & 0.43 & 0 & 1 & GEnt & 53 & 0.71 & 0.45 & 0 & 1 & 0.49 \\
\hline Stage & 46 & 0.56 & 0.50 & 0 & 1 & Stage & 53 & 0.54 & 0.50 & 0 & 1 & -0.17 \\
\hline Tequity & 46 & 0.52 & 0.50 & 0 & 1 & Tequity & 53 & 0.43 & 0.50 & 0 & 1 & -0.86 \\
\hline Rleader & 46 & 0.67 & 0.47 & 0 & 1 & Rleader & 53 & 0.69 & 0.46 & 0 & 1 & 0.25 \\
\hline
\end{tabular}

* The mean in reais of the financing goal for successful campaigns was $R \$ 316,227.77$ and for failed campaigns it was $R \$$ $154,881.66$. It is possible to verify that the t test for the means of the successful and failed campaigns was only significant for Lgoal (financial goal) and for Advisor (participation of an advisor in the startup financing campaign).

*** $=p<0.01 ; * *=p<0.05$.

Source: Elaborated by the authors

Table 3

Correlations and variance inflation factor (VIF)

\begin{tabular}{|c|c|c|c|c|c|c|c|c|c|c|c|c|c|}
\hline & 1 & & 2 & 3 & & 4 & 5 & & 6 & 7 & & 8 & VIF \\
\hline 1. Success & 1 & & & & & & & & & & & & \\
\hline 2. Lgoal & 0.199 & $* *$ & 1 & & & & & & & & & & 1.10 \\
\hline 3. Category & -0.107 & & 0.059 & 1 & & & & & & & & & 1.30 \\
\hline 4. Advisor & 0.290 & $* *$ & 0.059 & 0.094 & & 1 & & & & & & & 1.08 \\
\hline 5. Duration & 0.138 & & 0.019 & 0.087 & & 0.089 & 1 & & & & & & 1.29 \\
\hline 6. GEnt & 0.050 & & -0.118 & -0.326 & $* *$ & -0.142 & 0.006 & & 1 & & & & 1.18 \\
\hline 7. Stage & 0.018 & & 0.056 & -0.059 & & -0.176 & -0.113 & & 0.021 & 1 & & & 1.27 \\
\hline 8. Tequity & 0.088 & & -0.104 & 0.156 & & -0.037 & -0.412 & $* *$ & -0.076 & -0.045 & & 1 & 1.36 \\
\hline 9. Rleader & -0.026 & & -0.016 & -0.061 & & -0.030 & -0.124 & & 0.092 & 0.404 & $* *$ & 0.031 & 1.23 \\
\hline
\end{tabular}

$* *=5 \%$ statistical significance.

Source: Elaborated by the author. 


\section{DISCUSSION OF THE RESULTS}

It is possible to observe, through estimated models in Table 4, that hypothesis $\mathrm{H}_{1}$ was not rejected, as there was a significant and positive association between the goal of the venture and its success $\left(\beta_{1}=0.164 ; p<0.05\right)$. It can thus be stated that the goal established by the entrepreneurs has a positive influence on the probability of success of the campaign of an ECF venture. This result converges with the study by Ahlers et al. (2015) for the ECF market, but is inconsistent with the findings presented by Mollick (2014), who investigated reward-based crowdfunding and concluded that the higher the goal of the campaign, the lower the chances of obtaining success.

Hypothesis $\mathrm{H}_{2}$, which relates to the categories of ECF campaigns, whether financing projects for products or services, was also not rejected; that is, the variable of interest obtained a significant and positive parameter $\left(\beta_{2}=0.331 ; p<0.01\right)$. Ventures that were related to the creation of a product presented a higher probability of success compared to those that were linked to services. This evidence may reveal the preference of consumers in the ECF market for businesses that presented main activities linked to products; that is, the tangibility factor (Belleflamme et al., 2014) may somehow make a difference in regard to the decision to invest in ECF. Strauz (2017) made a similar finding to that of the present study, but regarding the reward-based crowdfunding market.

Table 4

Logit modeling for the success of equity crowdfunding (ECF) ventures

\begin{tabular}{|c|c|c|c|c|c|}
\hline & Model 1 & Model 2 & Model 3 & Model 4 & Model 5 \\
\hline \multicolumn{6}{|c|}{ Venture profile } \\
\hline \multirow{2}{*}{ Lgoal } & & $0.147^{*}$ & $0.152^{* *}$ & $0.145^{*}$ & $0.164^{* *}$ \\
\hline & & $(0.083)$ & $(0.076)$ & $(0.080)$ & $(0.086)$ \\
\hline \multirow{2}{*}{ Category } & $0.306^{* * *}$ & & $0.273^{* *}$ & $0.255^{* *}$ & $0.331^{* * *}$ \\
\hline & $(0.127)$ & & $(0.119)$ & $(0.124)$ & $(0.133)$ \\
\hline \multirow{2}{*}{ Advisor } & $0.384 * * *$ & $0.361^{* * *}$ & & $0.373^{* * *}$ & $0.392^{* * *}$ \\
\hline & $(0.107)$ & $(0.109)$ & & $(0.103)$ & (0.109) \\
\hline \multirow{2}{*}{ Duration } & $0.003^{* *}$ & $0.002^{*}$ & $0.003 * *$ & & $0.003^{* * *}$ \\
\hline & $(0.002)$ & $(0.001)$ & $(0.001)$ & & $(0.002)$ \\
\hline \multicolumn{6}{|l|}{ Controls } \\
\hline \multirow{2}{*}{ GEnt } & 0.020 & 0.155 & 0.004 & 0.072 & 0.039 \\
\hline & $(0.140)$ & $(0.120)$ & $(0.146)$ & $(0.134)$ & $(0.149)$ \\
\hline \multirow{2}{*}{ Stage } & 0.143 & 0.133 & 0.037 & 0.082 & 0.126 \\
\hline & $(0.134)$ & $(0.139)$ & $(0.120)$ & $(0.136)$ & $(0.138)$ \\
\hline \multirow{2}{*}{ Tequity } & $0.328^{* * *}$ & $0.282^{* *}$ & $0.322^{* * *}$ & $0.235^{* *}$ & $0.377^{* * *}$ \\
\hline & $(0.127)$ & $(0.132)$ & $(0.117)$ & $(0.120)$ & $(0.138)$ \\
\hline \multirow{2}{*}{ Rleader } & -0.092 & -0.067 & -0.036 & -0.082 & -0.085 \\
\hline & $(0.140)$ & $(0.134)$ & $(0.131)$ & $(0.143)$ & $(0.135)$ \\
\hline \multicolumn{6}{|l|}{ Fixed effects } \\
\hline Year & Yes & Yes & Yes & Yes & Yes \\
\hline McF.Adj R² & $19 \%$ & $17 \%$ & $17 \%$ & $14 \%$ & $22 \%$ \\
\hline $\mathrm{AIC}$ & 133.307 & 135.128 & 140.377 & 134.379 & 131.137 \\
\hline $\mathrm{BIC}$ & 161.853 & 163.674 & 168.923 & 162.925 & 162.278 \\
\hline $\mathrm{N}$ & 99 & 99 & 99 & 99 & 99 \\
\hline
\end{tabular}

Note: This table presents marginal effects of the independent variables on the dependent variable success (dummy 1 for success; 0 otherwise). (Robust) standard error of the estimate in parentheses. The estimation of the models considered the year dummy to create fixed effects in the times observed. As additional information, the number of ventures (category 1 startups, that is, offering a product) that presented both certifiers (Advisor and Rleader) was 25 campaigns, and for category 0 (startups offering services), the number of campaigns that had both certifiers was only 19.

$A I C=$ Akaike information criterion; BIC $=$ Schwarz Bayesian information criterion.

*** $=p<0.01 ;{ }^{* *}=p<0.05 ;{ }^{*}=p<0.1$.

Source: Elaborated by the authors. 
Hypothesis $\mathrm{H}_{3}$, in turn, was supported, given that the variable advisor (participation of a qualified investor) in the ECF venture campaign showed a significant and positive association with the chance of campaign success $\left(\beta_{3}=0.392 ; \mathrm{p}<0.01\right)$. This finding must indicate that the presence of a more experienced investor in the fundraising process of a venture can influence the willingness of investors to participate in that round of investment. Such thinking is coherent when considering the findings of the research by Moritz et al. (2015), who suggest that the involvement of experienced people in collective financing campaigns should reduce the information asymmetries in that market. The opinions and qualifications of these people may signal more security and credibility regarding the business evaluated (Dranove \& Jin, 2010).

The duration of the financing campaign of ECF ventures was also revealed to be equally important in terms of the probability of obtaining success. This variable presented a significant and positive parameter $\left(\beta_{4}=0.003\right.$; $\mathrm{p}<0.01$ ); that is, the number of days over which the ECF venture engages in raising financial resources is relevant for it obtaining success. Campaigns with more days of exposure (fundraising time) tend to be more successful than others with shorter exposure periods. This finding is in line with the studies by Ahlers et al. (2015) and by Vismara (2016b) for the ECF market and with the research by Burtch, Ghose, and Wattal (2013) for the reward-based crowdfunding market.
After testing the hypotheses presented by the study, we sought to study the effect of the control variables over the success of ECF ventures. Thus, the control variables GEnt (entrepreneur's gender), Stage (stage of the venture), and Rleader (round led by an angel investor, investment funds, or syndicates that invest in startups) were shown to have no significant influence over ECF campaign success. Only the control Tequity presented a significant and positive influence over the chance of success of the ventures $\left(\beta_{7}=0.377 ; \mathrm{p}<0.01\right)$; put in another way, the type of equity offered to investors was revealed to be able to positively influence the probability of success of the ventures. Businesses that offered pre-established equity, that is, where the investor would receive a value proportional to what was invested in the startup (ECF venture), presented a higher probability of success when compared to those that offered variable equity to investors.

\subsection{Additional Analyses}

Figure 2 presents the distribution histogram of the the campaigns success time (considering the number of days for the success) of the ventures that sought financing via ECF. This figure suggests that a high portion of the campaigns achieves venture success in the period close to the $50^{\text {th }}$ day of their campaign and, after that period, a strong reduction is observed in the number of ventures that achieve their financial objective.

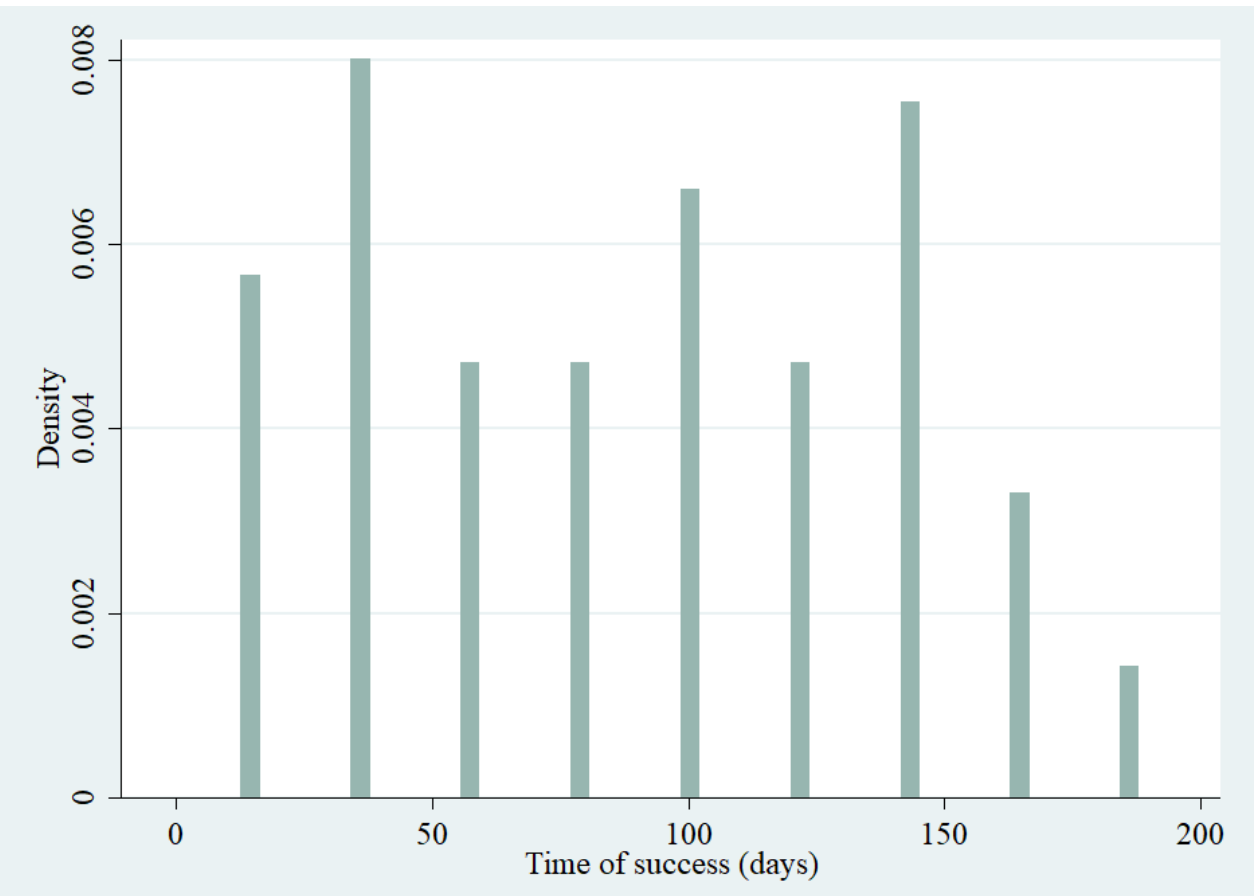

Figure 2 Distribution of the success time of the equity crowdfunding (ECF) campaigns

Note: This figure presents the concentration of ventures that managed to obtain success over the course of their ECF financing campaigns.

Source: Elaborated by the authors. 
However, the histogram also showed that many ventures that do not obtain success in the first 50 days of their campaigns tend to achieve their financial goals only when they reach around the $150^{\text {th }}$ day. It is also observed that ventures that present campaigns longer than 150 days tend to be failures.

In total, of the 99 ventures analyzed in this study, 46 were capable of obtaining success in their ECF financing campaigns. The average time of existence of a project until obtaining success is more than 88 days, with the fastest financing campaign being four days and the longest one being 197 days. The campaign that took 197 days was not developed in the period when the CVM regulated the maximum timeframe of 180 days (CVM instruction 588 ); it concerns a campaign undertaken in 2015 , which obtained a longer timeframe so that it could complete its funding process. In contrast, the campaign that lasted only four days was taken down as it was not in compliance with the financing rules that the Kria platform adopted in 2016.

Figure 3 presents the survival (A) and risk (B) functions estimated by the Kaplan-Meier non-parametric model. These functions suggest that venture survival decreases over the duration of the campaigns fundraising; that is, the risk (chance) of success of these ventures rises with longer fundraising periods, such as after 50, 100, and 150 days of fundraising.

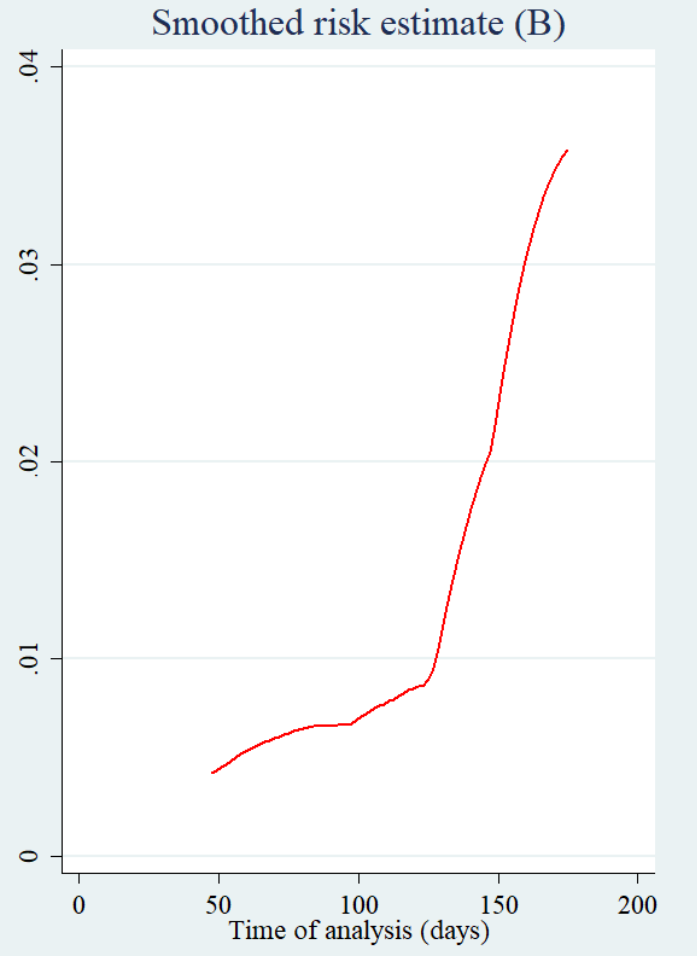

Figure 3 Kaplan-Meier curves for the success of the equity crowdfunding (ECF) campaigns

Note: This figure presents the survival function (A) and risk function (B) estimated for the time taken until the success of the ECF campaigns. Based on this figure, it can be understood that, as time passes, campaign survival decreases; that is, the ventures become successful, especially after the $50^{\text {th }}$ day of fundraising. Moreover, the longer the duration of the ECF venture campaign, the higher the chance of it obtaining success.

Source: Elaborated by the authors.

The risk function, presented in Figure 3B, presented monotonic behavior, that is, rising with the preservation of the order relation. Based on this evidence and knowing that the Weibull and Gompertz parametric distributions resemble that monotonic behavior, this paper examines the influence of the variables of interest over the time of success of the ECF ventures by implementing semiparametric models (Cox regressions) and (Weibull and Gompertz) parametric models, as presented in Table 5.
These models enabled the use of dependent covariables of the success time of the observed data. Moreover, this specification and the censoring technique used by the survival models should help in controlling individual characteristics of the set of observations and in understanding the entry and exit dynamic of individuals in the failure events (conventional term in the statistic). Failure in the survival models was treated here as the closure of the ECF campaigns, that is, based on a particular venture obtaining success. 
Table 5

Risk ratios (proportional hazards - PH) and success time (accelerated failure time - AFT) for the equity crowdfunding (ECF) campaigns

\begin{tabular}{|c|c|c|c|}
\hline & & Models & \\
\hline & Cox & Weibull & Gompertz \\
\hline \multicolumn{4}{|c|}{ Venture profile } \\
\hline \multirow{2}{*}{ Lgoal } & $1.622^{* *}$ & $0.631^{* *}$ & $0.732^{* *}$ \\
\hline & $(0.373)$ & $(0.373)$ & $(0.401)$ \\
\hline \multirow{2}{*}{ Category } & $1.640^{*}$ & $0.573^{*}$ & $0.601 *$ \\
\hline & $(0.206)$ & $(0.181)$ & $(0.191)$ \\
\hline \multirow{2}{*}{ Advisor } & $1.763^{*}$ & $0.920^{*}$ & $0.905^{*}$ \\
\hline & $(0.690)$ & $(0.749)$ & $(0.744)$ \\
\hline \multicolumn{4}{|l|}{ Controls } \\
\hline \multirow{2}{*}{ GEnt } & 1.523 & 0.391 & 0.551 \\
\hline & $(0.620)$ & $(0.543)$ & $(0.620)$ \\
\hline \multirow{2}{*}{ Stage } & 1.448 & 0.504 & 0.412 \\
\hline & $(0.574)$ & $(0.591)$ & $(0.558)$ \\
\hline \multirow{2}{*}{ Tequity } & $1.845^{* *}$ & $0.209^{* * *}$ & $0.238^{* * *}$ \\
\hline & $(0.967)$ & $(1.070)$ & $(1.101)$ \\
\hline \multirow{2}{*}{ Rleader } & 1.038 & 0.015 & 0.082 \\
\hline & $(0.430)$ & $(0.414)$ & $(0.449)$ \\
\hline $\mathrm{AIC}$ & 317.407 & 128.015 & 129.156 \\
\hline $\mathrm{BIC}$ & 335.573 & 151.371 & 152.512 \\
\hline $\mathrm{n}$ & 46 & 46 & 46 \\
\hline
\end{tabular}

Note: The estimated Cox model is in the proportional hazards $(\mathrm{PH})$ metric, whose interpretation is based on the chance of success. The Weibull and Gompertz models are in the acceleration of failure time (AFT) metric and were used in the economic interpretations of the results reported in this table.

AIC = Akaike information criterion; BIC = Schwarz Bayesian information criterion.

Source: Elaborated by the authors.

Unlike the Cox proportional-hazards (PH) metric, the Weibull and Gompertz models, estimated in Table 5 , are in the accelerated failure time (AFT) metrics. As the Akaike information criterion (AIC) and the Schwarz Bayesian information criterion (BIC) indicated that the statistical analyses should be carried out using the parametric models, these models were used in the economic interpretations. The results reported in Table 5 suggest that ventures with higher financing goals may have a shorter time until success. Put in another way, an increase in the goal can accelerate the success of the venture by up to $34 \%$ (Weibull model); that is, businesses with higher financial goals tend to obtain success more quickly when compared to the rest. It is probable that, as an investment is concerned, the higher the financial goal is of the available venture, the higher the equity or the profit promised to the investor should be (Ahlers et al., 2015).

The venture category was also revealed to be significant for the time of success of the ECF campaigns. The ventures that were linked to products presented up to $43 \%$ faster success than those that involved services (Weibull model). This finding must reveal the preference of investors for depositing their financial resources in startups linked to the creation of products when compared to services.

ECF ventures that presented an advisor in their financing campaigns tend to obtain success up to $8 \%$ more quickly (Weibull model) during their fundraising period. This reinforces the suppositions found by the logit modeling in the previous section and corroborates the defense of the argument that the presence of more qualified (experienced) investors in ECF ventures can both increase their probability of success and accelerate the time taken until success.

With relation to the controls tested, to the entrepreneur's gender, to the stage of the venture, and to the led round, these were not significant in accelerating or reducing the time taken until campaign success. In contrast, the type of equity offered to the investors was revealed to be capable of influencing the time taken for the ventures to obtain success. Businesses that offered pre-established equity presented almost 79\% more instantaneous chances of success (Weinbull model) than the other ventures that offered variable financial equity. 


\section{CONCLUDING REMARKS}

In this study, we examined the elements linked to the general characteristics of the ventures of one of the biggest ECF platforms in Brazil that have an influence over the success of the startup financing campaigns.

The general results of the research indicate that the financial goal of the ventures, the category these ventures form part of, the participation of experienced investors during the fundraising process, the duration of the campaigns (number of days that the venture remains online), and the type of equity offered to investors can together have an impact on the probability of success of the campaigns of ventures seeking ECF financing. Moreover, the additional analyses carried out enable the understanding that such elements are also capable of accelerating the time taken for the campaign to obtain success.

Ventures with higher financial goals presented more chances of success and a more accelerated time of success in relation to the rest. This must occur because the greater the funds raised for the venture, the more equity will be offered in exchange for the investment. Businesses that were linked to the development of products, and not services, presented more chances of success, and more accelerated success when compared to the rest. The participation of an advisor, that is, of a qualified investor, was also revealed to be an essential element for the success of the ECF campaigns analyzed, regarding both the probability and the time of success.

Campaigns that engage in fundraising over a longer time period can have more chances of success, such as campaigns over 50, 100, and 150 days. Finally, businesses that offered pre-established equity showed a higher probability of success, and quicker success in relation to businesses that reserved variable equity for investors.

In light of the above, it is believed that this study contributes with new information regarding the dynamic of the success of ventures financed via ECF. Based on the logit modeling (probability of success) and the survival analysis (time taken until success), it was possible to understand how the elements linked to the profile of the startups can influence the success of their campaigns. Via the empirical results found, it can be concluded that the allocation of financial resources in the ECF market must be sensitive to the general attributes of the startup financing campaign itself.

The findings revealed here should play an important role in the decision making of future entrepreneurs and investors in the ECF market, in that, by knowing the characteristics of startup financing campaigns, the investor can best choose the campaigns with more chances of success, that is, those that will be able to pay them back the capital invested. In contrast, this information can be used by entrepreneurs to develop more attractive strategies, which can be used to attract investors to their businesses.

The design of this research imposes limitations on the study, which may restrict generalizations of the results obtained. A number of aspects warranting attention can be mentioned: (i) the study is limited to the Brazilian context; (ii) the moment in which the data were collected may produce specific behaviors of the variables observed. Moreover, studies regarding ECF are relevant as they help in understanding new economic relationships and alternative financing models, which seek to solve problems of scarce credit for recently-created micro and small businesses (Cumming, Vanacker, \& Zahra, 2019a).

For future studies, we highlight the possibility of investigating the impact of the (recent) CVM legislation over the ECF market, e.g., models of the natural experiment type and DID (difference-in-differences) models, or even other success metrics (Chan, Park, Patel, \& Gomulya, 2018). Finally, it warrants mentioning that the literature on startup financing via ECF in Brazil is still scarce (Felipe et al., 2019), revealing the relevance of this study and its role as a way of incentivizing the production of research on the topic addressed here. 


\section{REFERENCES}

Agente de Estruturação Ltda. (2019a). Material didático para investidores. Retrieved from https://www.basement.io/ material-didatico-para-investidores

Agente de Estruturação Ltda. (2019b). Por que investir com o Kria? Retrieved from https://www.kria.vc/

Agrawal, A., Catalini, C., \& Goldfarb, A. (2016). Are syndicates the killer app of equity crowdfunding? California Management Review, 58(2), 111-124.

Ahlers, G. K., Cumming, D., Günther, C., \& Schweizer, D. (2015). Signaling in equity crowdfunding. Entrepreneurship Theory and Practice, 39(4), 955-980.

Allison, T. H., Davis, B. C., Short, J. C., \& Webb, J. W. (2015). Crowdfunding in a prosocial microlending environment: Examining the role of intrinsic versus extrinsic cues. Entrepreneurship Theory and Practice, 39(1), 53-73.

Amedomar, A. D. A. (2015). O crowdfunding de recompensas como alternativa de capital empreendedor para EBTs no Brasil: um estudo descritivo-exploratório (Master's Dissertation). Universidade de São Paulo, São Paulo.

Araújo, M. D. M. D. (2017). Crowdfunding: o que as campanhas de sucesso fazem diferente? Uma análise comparativa com uso de conjuntos fuzzy set (Master's Dissertation). Universidade do Vale do Rio dos Sinos, São Leopoldo.

Bapna, S. (2016). The independent and combined effects of external endorsements on equity crowdfunding investments. In Academy of Management Proceedings (Vol. 2016, n. 1, p. 10465). Briarcliff Manor, NY.

Belleflamme, P., Lambert, T., \& Schwienbacher, A. (2014). Crowdfunding: Tapping the right crowd. Journal of Business Venturing, 29(5), 585-609.

Belleflamme, P., Omrani, N., \& Peitz, M. (2015). The economics of crowdfunding platforms. Information Economics and Policy, 33(1), 11-28.

Berger, A. N., Espinosa-Vega, P. I., Frame, W. S., \& Miller, N. H. (2005). Debt, maturity, risk, and asymmetric information. Journal of Finance, 60(1), 2895-2923.

Block, J., Hornuf, L., \& Moritz, A. (2018). Which updates during an equity crowdfunding campaign increase crowd participation? Small Business Economics, 50(1), 3-27.

Burtch, G., Ghose, A., \& Wattal, S. (2013). An empirical examination of the antecedents and consequences of contribution patterns in crowd-funded markets. Information Systems Research, 24(3), 499-519.

Chan, C. R., Park, H. D., Patel, P., \& Gomulya, D. (2018). Rewardbased crowdfunding success: Decomposition of the project, product category, entrepreneur, and location effects. Venture Capital, 20(3), 285-307.

Chesbrough, H. (2010). Business model innovation: Opportunities and barriers. Long Range Planning, 43(2), 354-363.

Clarke, S. (2016). Wisdom and learning: Equity crowdfunding's role in reducing information asymmetries. In Academy of Management Proceedings (Vol. 2016, n. 1, p. 10465). Briarcliff Manor, NY.
Colombo, M. G., Franzoni, C., \& Rossi-Lamastra, C. (2015). Internal social capital and the attraction of early contributions in crowdfunding. Entrepreneurship Theory and Practice, 39(1), 75-100.

Comissão de Valores Mobiliários (Brazilian capital market regulator). (2017). CVM Instruction 588, of July $14^{\text {th }}$ of 2017. Describes the public offering of small-sized company securities, waivering registration through a participative investment electronic platform, and alters the arrangements of CVM Instruction 400, of December $29^{\text {th }}$ of 2003, of CVM Instruction 480, of December $7^{\text {th }}$ of 2009, of CVM Instruction 510, of December $5^{\text {th }}$ of 2011, and of CVM Instruction 541, of December $20^{\text {th }}$. Retrieved from http://www.cvm.gov.br/ legislacao/instrucoes/inst588.html

Cumming, D. J., Pandes, J. A., \& Robinson, M. J. (2013). The role of agents in private entrepreneurial finance. Entrepreneurship Theory and Practice, 39(2), 345-374.

Cumming, D. J., Vanacker, T., \& Zahra, S. A. (2019a). Equity crowdfunding and governance: Toward an integrative model and research agenda. Academy of Management Perspectives, 33. https://dx.doi.org/10.5465/amp.2017.0208

Cummings, M. E., Rawhouser, H., Vismara, S., \& Hamilton, E. L. (2019b). An equity crowdfunding research agenda: Evidence from stakeholder participation in the rulemaking process. Small Business Economics, 1-26. https://doi. org/10.1007/s11187-018-00134-5

Da Cruz, J. V. (2015). Competition and regulation of crowdfunding platforms: A two-sided market approach. Communications \& Strategies, 99(1), 33-50.

De Buysere, K., Gajda, O., Kleverlaan, R., Marom, D., \& Klaes, M. (2012). A framework for European crowdfunding. Retrieved from https://www.fundraisingschool.it/wp-content/ uploads/2013/02/European-Crowdfunding-FrameworkOct-2012.pdf

Dranove, D., \& Jin, G. Z. (2010). Quality disclosure and certification: Theory and practice. Journal of Economic Literature, 48(4), 935-963.

Drover, W., Busenitz, L., Matusik, S., Townsend, D., Anglin, A., \& Dushnitsky, G. (2017). A review and road map of entrepreneurial equity financing research: Venture capital, corporate venture capital, angel investment, crowdfunding, and accelerators. Journal of Management, 43(6), 1820-1853. https://doi.org/10.1177\%2F0149206317690584

Felipe, I. J. dos S. (2015). Shared value creation and crowdfunding in Brazil. Journal of Financial Innovation, 1(3), 213-230. https://doi.org/10.15194/jofi_2015.v1.i3.39

Felipe, I. J. dos S. (2017). Determinantes do sucesso de campanhas de equity e de reward crowdfunding (Doctoral Thesis). Fundação Getulio Vargas, São Paulo.

Felipe, I. J. dos S., Mendes-Da-Silva, W., Gattaz, C. C. (2019). Crowdfunding research agenda: Semantic analysis of the media and geography of investments. Encyclopedia with Semantic Computing and Robotic Intelligence, 2, 193001-19300010. https://doi.org/10.1142/S2529737619300018 
Greenberg, J., \& Mollick, E. (2015). Leaning in or leaning on? Gender, homophily, and activism in crowdfunding. In Academy of Management Proceedings (Vol. 2016, n. 1, p. 10465). Briarcliff Manor, NY. http://dx.doi.org/10.5465/ AMBPP.2015.18365abstract

Haas, P., Blohm, I., \& Leimeister, J. M. (2014). An empirical taxonomy of crowdfunding intermediaries. Retrieved from https://aisel.aisnet.org/icis2014/proceedings/ SocialMedia/13/

Hornuf, L., \& Schwienbacher, A. (2018). Market mechanisms and funding dynamics in equity crowdfunding. Journal of Corporate Finance, 50(1), 556-574.

Hossain, M., \& Oparaocha, G. O. (2017). Crowdfunding: Motives, definitions, typology and ethical challenges. Entrepreneurship Research Journal, 7(2), 1-14. https://doi.org/10.1515/erj-20150045

Kuppuswamy, V., \& Bayus, B. L. (2017). Does my contribution to your crowdfunding project matter? Journal of Business Venturing, 32(1), 72-89.

Lukkarinen, A., Teich, J. E., Wallenius, H., \& Wallenius, J. (2016). Success drivers of online equity crowdfunding campaigns. Decision Support Systems, 87(1), 26-38.

Mahmood, A., Luffarelli, J., \& Mukesh, M. (2019). What's in a logo? The impact of complex visual cues in equity crowdfunding. Journal of Business Venturing, 34(1), 41-62.

Marom, D., Robb, A., \& Sade, O. (2014). Gender dynamics in crowdfunding (kickstarter): Evidence on entrepreneurs, investors, deals, and taste-based discrimination [Working Paper]. Social Science Research Network.

Massolution. (2015). 2015CF. Crowdfunding industry report. Retrieved from http://www.smv.gob.pe/Biblioteca/temp/ catalogacion/C8789.pdf

Mollick, E. (2014). The dynamics of crowdfunding: An exploratory study. Journal of Business Venturing, 29(1), $1-16$.
Monteiro, M. D. C. P. (2014). Crowdfunding no Brasil: uma análise sobre as motivações de quem participa (Master's Dissertation). Fundação Getulio Vargas, São Paulo.

Moritz, A., Block, J., \& Lutz, E. (2015). Investor communication in equity-based crowdfunding: A qualitative-empirical study. Qualitative Research in Financial Markets, 7(3), 309-342.

Piva, E., \& Rossi-Lamastra, C. (2018). Human capital signals and entrepreneurs' success in equity crowdfunding. Small Business Economics, 51(3), 667-686.

Prpić, J., \& Shukla, P. (2013). The theory of crowd capital. In Annals of the 2013 46th Hawaii International Conference on System Sciences (p. 3505-3514).

Schwienbacher, A., \& Larralde, B. (2010). Crowdfunding of small entrepreneurial ventures. In Handbook of entrepreneurial finance: Oxford University Press, Oxford.

Signori, A., \& Vismara, S. (2018). Does success bring success? The post-offering lives of equity-crowdfunded firms. Journal of Corporate Finance, 50(1), 575-591.

Strausz, R. (2017). A theory of crowdfunding - a mechanism design approach with demand uncertainty and moral hazard. American Economic Review, 107(6), 1430-1476.

Vismara, S. (2016a). Equity retention and social network theory in equity crowdfunding. Small Business Economics, 46(4), 579-590.

Vismara, S. (2016b). Information cascades among investors in equity crowdfunding. Entrepreneurship Theory and Practice, 42(3), 467-497.

Vismara, S. (2019). Sustainability in equity crowdfunding. Technological Forecasting and Social Change, 141(1), 98-106.

Vulkan, N., Åstebro, T., \& Sierra, M. F. (2016). Equity crowdfunding: A new phenomenon. Journal of Business Venturing Insights, 5(1), 37-49.

Walthoff-Borm, X., Schwienbacher, A., \& Vanacker, T. (2018). Equity crowdfunding: First resort or last resort? Journal of Business Venturing, 33(4), 513-533. 